Научная статья

УДК 37.018.4:004

DOI: $10.18101 / 2307-3330-2021-3-60-63$

\title{
ИСПОЛЬЗОВАНИЕ ИНФОРМАЦИОННЫХ ТЕХНОЛОГИЙ В ПРОЦЕССЕ ОБУЧЕНИЯ МОЛОДЫМИ ПЕДАГОГАМИ В ПЕРИОД ПАНДЕМИИ
}

\author{
(c) Бальчинова Марина Геннадьевна \\ магистрант, \\ Бурятский государственный университет имени Доржи Банзарова \\ Россия, 670000, г. Улан-Удэ, ул. Смолина, 24a \\ marina.bal4inova@gmail.com
}

\begin{abstract}
Аннотация. Статья посвящена информационным технологиям, использованным в процессе обучения молодыми педагогами в период пандемии. В статье рассматриваются такие вопросы, как современное образование, дистанционное обучение и его цели, а также факторы, влияющие на его успешность, метод групповой работы, например, scrum-метод.

В наше время преобладание «цифрового поколения» внесло определенную специфику в когнитивную, эмоционально-волевую, социальную сферы личности. Методы группового самообучения сегодня как никогда подходят для проведения уроков. Метод scrum привлек к себе внимание преподавателей своей интерактивностью, а самое главное, широкими возможностями для самостоятельной работы учеников, что является актуальным в период пандемии.
\end{abstract}

Ключевые слова: дистанционное обучение, образование, метод группового обучения, молодые педагоги, информационные технологии, пандемия.

\section{Для цитирования}

Бальчинова М. Г. Использование информационных технологий в процессе обучения молодыми педагогами в период пандемии // Вестник Бурятского государственного университета. Образование. Личность. Общество. 2021. № 3. С. 60-63.

Состояние, в котором сегодня оказался весь мир из-за вспышки коронавирусной инфекции, заставило поменять образ жизни многих людей, также это затронуло и образование. Перейдя на дистанционное обучение, вопрос о развитии информационных технологий в процессе образования стал более актуальным, ситуация с коронавирусом показала, что цифровые навыки из желательных становятся обязательными и необходимыми.

Сегодня изменилось все - и пространство уроков, и временные затраты на них в онлайн-режиме, и в домашней самостоятельной работе учащихся, и самое главное - изменились способы восприятия детьми знаний и информации. В эпоху доминирования «цифрового поколения» приобрели свою специфику когнитивная, эмоционально-волевая, социальная сферы личности.

Современные школьники не только получают информацию из информационных источников, но и активно коммуницируют с ними. Цифровая социализация сегодня дополняет традиционную социализацию, являясь ее важной частью, а 
М. Г. Бальчинова. Использование информационных технологий в процессе обучения молодыми педагогами в период пандемии

развивающаяся цифровая культура дополняет культуру офлайн-повседневности, представляя новый этап развития общества, настоятельно требующий новых взглядов и подходов.

Современное общество характеризуется стремительными обновлениями во всех сферах профессиональной деятельности; предъявляются новые, более высокие требования к профессиональному становлению молодых специалистов. Дистанционная форма образования рассматривалась в первую очередь как альтернативная очной и заочной форме обучения и призвана была реализовать следующие цели:

- обеспечить доступ различным категориям населения к качественным образовательным услугам;

- увеличение контингента обучающихся за счет предоставления возможности освоения образовательных программ в максимально удобной форме;

- повышение качества подготовки обучающихся за счет внедрения информационно-коммуникационных технологий и компьютерных средств обучения;

- минимизация затрат на организацию и реализацию учебного процесса.

До 2020 г. дистанционная форма обучения применялась исключительно в вузах, но в связи со вспышкой коронавируса (COVID-19) в мире в декабре $2019-$ начале 2020 г. эта форма оказалась единственно доступной вузам и школам. Таким образом, уже в марте 2020 г. Министерство образования Российской Федерации рекомендовало образовательным учреждениям организовать обучение студентов с использованием цифровых образовательных технологий вне места нахождения организаций в связи с неблагоприятной эпидемиологической обстановкой.

На дистанционном обучении на уроках сложно наилучшим образом организовать урок, молодые педагоги считают, что лучшим средствами по преодолению такой ситуации могут быть диалог и эвристическая беседа с применением интерактивных технологий с помощью различных платформ (ZOOM, Discord и др.), а также методы групповой работы, например, scrum-метод.

Scrum (скрам) - это один из agile-подходов к разработке и управлению проектами. Чаще всего данный метод используют в IT-сфере, однако он применим для разных направлений, включая строительство, образование, производство товаров, ивент-индустрию и другие виды деятельности.

Методы групповой самостоятельной работы как никогда подходят сегодня для проведения уроков. Scrum-метод недавно стал распространяться в образовании, но уже привлек внимание многих педагогов своей интерактивностью, а главное - широкими возможностями для самостоятельной работы учащихся. Скрам-метод, как и другие методы групповой работы на уроках литературы, позволяет учащимся актуализировать ее восприятие, самостоятельно погрузиться в мир художественных образов, способствует освоению тропов и фигур, других средств художественной выразительности, формируя при этом нравственноэстетический опыт личности.

«Главной угрозой для преподавателей стала не необходимость овладения онлайн-инструментами, а новые возможности контроля образовательного процесса 
университетской бюрократией, которая в ряде случаев стала указывать на необходимость работы на определенных платформах и как себя вести, что может, в свою очередь, привести к утрате свободы преподавания», - заявил директор лаборатории методологии социальных исследований РАНХиГС Дмитрий Рогозин.

В то же время чтобы эффективно функционировать, дистанционная форма обучения должна претерпеть немало изменений в различных направлениях, основные из них:

1. Профессиональная переподготовка и повышение квалификации педагогических кадров.

2. Создание и совершенствование стабильных и удобных образовательных площадок.

3. Обновление информационно-технической базы образовательных учреждений.

4. Внесение изменений в текущие образовательные программы с учетом специфики дистанционной формы обучения.

5. Создание новых методов взаимодействия преподавателей и обучающихся.

Остро стоит вопрос в области профессионального образования. Предстоит определить опытным путем, каким профессиям возможно обучить полностью в дистанционной форме, а для освоения которых будет необходима смешанная.

Одной из важнейших задач молодого педагога в период пандемии является способствование развитию современных навыков у школьников, таких как информационная и медиаграмотность, цифровое общение и сотрудничество, создание цифрового контента, ответственное использование цифровых ресурсов и решение технологических задач.

Опыт использования информационных технологий молодыми педагогами не только облегчает доступ к информации, открывает возможности вариативной учебной деятельности, ее индивидуализации и дифференциации, но и позволяет молодому педагогу по-новому, на более современном уровне организовать сам процесс обучения, построить его так, чтобы ученик был бы активным и равноправным его членом.

Благодаря современным технологиям процесс обучения не прерывается, но даже становится более разнообразным. Грамотное овладение молодыми педагогами инновационными технологиями позволяет изменить учебный процесс в лучшую, более комфортную сторону, охватывая все этапы учебной деятельности.

В заключение необходимо отметить, что сегодня во всем мире огромное внимание педагогического сообщества направлено на срочное формирование новых цифровых компетенций. Опыт молодых педагогов показал, что в современных условиях учителям необходимо максимально быстро учиться, осваивать современные технологии, овладевать новыми инструментами обучения и взаимодействия, а также внедрять в ежедневную работу все эффективные форматы обучения, что не составляет трудностей для нового поколения. Непрерывное обучение - вот к чему сегодня пришел весь мир, и на чем будет строиться наше будущее. Непрерывное обучение и для учеников, и для учителей - отныне только при таких условиях мы вырастим образованное, эрудированное новое поколение. 
М. Г. Бальчинова. Использование информационных технологий в процессе обучения молодыми педагогами в период пандемии

Лuтература

1. Бобр А. Д. О принципах групповой работы учащихся в рамках SCRUMтехнологии // Проблемы современной лингвистики и методики преподавания иностранных языков. Коломна: ГСГУ, 2020. С. 43-45. Текст: непосредственный.

2. Кувшинова Е. Е. Дистанционное обучение в условиях кризиса 2020 (на примере Финансового университета при Правительства РФ) // Современное педагогическое образование. 2020. № 4. С. 8-15. Текст: непосредственный.

3. Солдатова Г. У., Рассказова Е. И., Нестик Т. А. Цифровое поколение России: компетентность и безопасность. Москва: Смысл, 2017. 375 с. Текст: непосредственный.

Статья поступила в редакиию 18.11.2021; одобрена после рецензирования 22.11.2021; принята к публикации 07.12.2021.

\title{
THE USE OF INFORMATION TECHNOLOGY IN THE LEARNING PROCESS BY YOUNG TEACHERS DURING THE PANDEMIC
}

\author{
Marina G. Balchinova \\ Dorzhi Banzarov Buryat State University \\ 24a Smolina St., Ulan-Ude, 670000, Russia \\ marina.bal4inova@gmail.com
}

The article is devoted to the information technologies used in the learning process by young teachers during the pandemic. The core of the article is the questions such as modern education, distance learning and its objectives, as well as factors influencing its success, the method of group work, such as scrum-method.

Cognitive, emotional-volitional, social sphere of personality specified prevalence of «digital generation». Today methods of group self-learning are the most suitable for lessons. Scrum method has attracted the attention of teachers by its interactivity, and mainly, the ample opportunities for independent work of students, which is relevant during the pandemic.

Keywords: distance learning, education, group learning method, young teachers, information technology, pandemic.

The article was submitted 18.11.2021; approved after reviewing 22.11.2021; accepted for publication 07.12.2021. 